İşletme Akademisi Dergisi
2020, 1 (2): 162-173
DOI:10.2677/TR 1010.2020 .438
Dergi web sayfasi: www.sakder.org

Araștırma Makalesi

\title{
İş Doyumu, Yaşam Doyumu ve İşgören Performansı Arasındaki İlişki: Ankara'daki 4 ve 5 Yıldızlı Oteller Üzerinde Bir İnceleme
}

\author{
Dr. Öğr. Üyesi Şükran ÖKTEM
}

Başkent Üniversitesi, Bağlıca Kampüsü, Etimesgut, Ankara.

sukran@baskent.edu.tr www.orcid.org/0000-0003-2198-6449

\section{Dr. Öğr. Üyesi Menekşe ÖZTOPRAK}

Başkent Üniversitesi, Bağlıca Kampüsü, , Etimesgut, Ankara.

tarhan@baskent.edu.tr www.orcid.org/0000-0003-4039-3657

\section{Öz}

$\mathrm{Bu}$ araştırmanın amacı, örgütlerin başarısı açısından son derece önemli bir yönetim konusu olan iş doyumu, yaşam doyumu ve işgören performans düzeyleri arasındaki ilişkiyi ortaya koymaktır. $\mathrm{Bu}$ amaç doğrultusunda Ankara ilinde bulunan 4 ve 5 yıldızlı otellerde, tesadüfî olarak seçilen 319 çalışana, örneklem çapı basit tesadüfî örneklem yöntemi kullanılarak iş doyumu, yaşam doyumu ve performans ölçeğini içeren anketler uygulanmıştır. Elde edilen veriler SPSS paket programında frekans ve yüzde, korelasyon analizi, farklılaşma testleri $t$ ve anova testi ile analiz edilmiştir. Analiz sonucunda çalışanların iş doyumu ile yaşam doyumu arasında ilişki, iş doyumu ile işgören performansı arasında ilişki ve yaşam doyumu ile işgören performansı arasında ilişki tespit edilmiştir. Araştırma sonuçlarına göre; iş doyumu ve yaşam doyumu arasında, iş doyumu ile işgören performans düzeyi arasında anlamlı bir ilişkinin mevcut olduğu ancak yaşam doyumu ile işgören performansı arasında ise böyle bir ilişkinin olduğu görülememiştir.

Anahtar Kelimeler: İş Doyumu, Yaşam Doyumu, İşgören Performansı.

Makale Gönderme Tarihi: 08.02.2020

Makale Kabul Tarihi: 10.04 .2020

\section{Önerilen Atıf:}

Öktem, S., Öztoprak, M. (2020). İş Doyumu, Yaşam Doyumu ve İşgören Performansı Arasındaki İlişki: Ankara' daki 4 ve 5 Yıldızlı Oteller Üzerinde Bir İnceleme, İşletme Akademisi Dergisi, 1(2): 162-173.

(C) 2020 İşletme Akademisi Dergisi. 


Journal of Business Academy
2020,1(2): 162-176
DOI:10.26677/TR1010.2020.
Web pages: www.isakder.org

$\underline{\text { Research Article }}$

\title{
Relationship Between Job Satisfaction, Life Satisfaction and Employee Performance: A Review on 4 and 5 Star Hotels in Ankara
}

\author{
Assist. Prof. Şükran ÖKTEM \\ Başkent University, Bağlıca Campus, Etimesgut, Ankara, Turkey. \\ sukran@baskent.edu.tr www.orcid.org/0000-0003-2198-6449

\section{Assist. Prof. Menekşe ÖZTOPRAK} \\ Başkent University, Bağlıca Campus, , Etimesgut, Ankara, Turkey. \\ tarhan@baskent.edu.tr www.orcid.org/0000-0003-4039-3657
}

\begin{abstract}
The purpose of this research is to reveal the relationship between job satisfaction, life satisfaction and levels of employee performance, which is an important management issue for the success of organizations. For this purpose, on selected randomly 319 employees from 4 and 5-star hotels in Ankara, using sample diameter simple random sampling method a job satisfaction survey, including life satisfaction and performance scale was applied. The data obtained were analyzed by frequency and percentage, correlation analysis, differentiation tests $t$ and anova test in SPSS package program. As a result of the analysis, it has been identified the relationship between the job satisfaction and life satisfaction of employees, the relationship between job satisfaction and employee performance, and the relationship between life satisfaction and employee performance. According to the research results; It has been observed that there is a significant relationship between job satisfaction and life satisfaction, between job satisfaction and employee performance level, but there is no such relationship between life satisfaction and employee performance.
\end{abstract}

Keywords: Job Satisfaction, Life Satisfaction, Employee Performance.

Received: 08.02.2020

Accepted: 10.04 .2020

\section{Suggested Citation:}

Öktem, S., Öztoprak, M. (2020). Relationship Between Job Satisfaction, Life Satisfaction and Employee Performance: A Review on 4 and 5 Star Hotels in Ankara, Journal of Business Academy, 1(2): 162-173.

(C) 2020 Journal of Business Academy. 


\section{GİRIŞ}

Bilindiği üzere bir işletmenin hayatını sürdürebilmesi, nitelikli ve kaliteli üretim yapabilmesi için üretim faktörlerinin (Emek, Sermaye, Doğal Kaynaklar, Bilgi Kaynakları ve Girişimci) uyumlu bir şekilde çalışması gerekmektedir. Üretim faktörlerinden olan emek faktörünü oluşturan iş gücü yani çalışanların gerek kaynakları ekonomik etkin ve etkili kullanma gerekse de diğer faktörlerle ahenkli bir şekilde bir arada çalışabilmesi için işin uzmanı olma, motive olması, stresi yönetebilmesi vb. faktörlerin yanında kuruma aitlik duygusu ile bağlı olması, işini sevmesi ve kendini gösterebilmesi gerekmektedir. Dolayısıyla işinde doyuma ulaşmayan, üretemeyen çalışanın performansı düşük olacaktır. Herhangi bir kurumun başarısı ve verimliliği çalışanların iş doyumuna ve performanslarına bağlıdır. Çalışanların iş doyumu ve buna bağlı olarak performanslarını etkileyen pek çok faktör vardır. Ücret, terfi imkanları, sosyal haklar, iş arkadaşları ve yöneticilerle ilişkiler, güvenlik, verimlilik, çalışma koşulları, adil performans değerlendirmesi gibi konular yöneticilerin daha çok dikkat etmesini gerektirecek konulardan yalnızca birkaç tanesidir.

İş doyumunun gerçekleşmesiyle işgörenler iş yaşamında gerek kendisi için gerekse o işe özel belirlenen standartlara ve hedeflere ulaşabilirler. Bir başka deyişle performansları artar. İşgörenlerin performans artışları yalnızca iş doyumu ile ilişkili değildir, aynı zamanda iş dışındaki yaşamda da doyuma ulaşması, günlük yaşamında çevresiyle barışık olması, mutlu olması iş performansında önemli bir etkendir. Hatta iş dışındaki yaşamında mutlu olması iş doyumunu da kısmen olumlu etkileyebilir.

$\mathrm{Bu}$ araştırmada, çalışanların işlerinden ve yaşamlarından memnuniyet düzeylerini etkileyen faktörler incelenmiş, bu terimlerin arasındaki ilişkilere yer verilmiştir. Araştırmada ele alınan bu üç kavram, sadece iş hayatında işgörenlerle değil, eğitim hayatında öğrencilerle, özel hayatında aile bireyleriyle, sosyal hayat da arkadaş ve sosyal çevreyle de alakalı olabilir. İş doyumu, yaşam doyumu gibi insan doyumlarının seviyesi çeşitli etkenlere bağlıdır. Bu etkenlerin bazıları doyumu artırır hayattan keyif zevk almayı yaşam enerjisinin yüksek olmasını sağlarken bazıları da doyumu azaltarak kişinin yaşamdan kopmasına, tükenmesine, keyifsiz, mutsuz, amaçsız bir hayat sürmesine neden olabilir. Elbette ki yaşamın her alanında olumlu ve olumsuz etkenlerle karşlaşmak mümkündür. Olumlu etkenlere; motivasyon, ödüllendirme, saygınlık, zorunlukültürel-lüks olan tüm ihtiyaçları karşılayabilmek, kendini gerçekleştirme ihtiyacına yakınlık düzeyi, yaşanılan ülkenin gelişmişlik düzeyinin yüksek olması vb., olumsuz etkenlere ise; psikolojik şiddet, güvensizlik, gelecek kaygısı, aşırı stres, sürekli çatışma ortamında olmak, çalışma ortamının yada yaşanılan ortamın fiziksel şartlarının yetersiz olması, emniyetli olmaması, hayat standardından memnuniyetsizlik vb. etkenler örnek olarak verilebilir. Bu araştırmada; iş doyumu, yaşam doyumu ve iş gören performansı arasında anlamlı ilişkiler olduğu tespit edilmiş olup, bu ilişkilerin düzeyi analizler sonucu ortaya konulmuştur.

Araştırmanın modeli aşağıdaki şekilde oluşturulmuştur. 


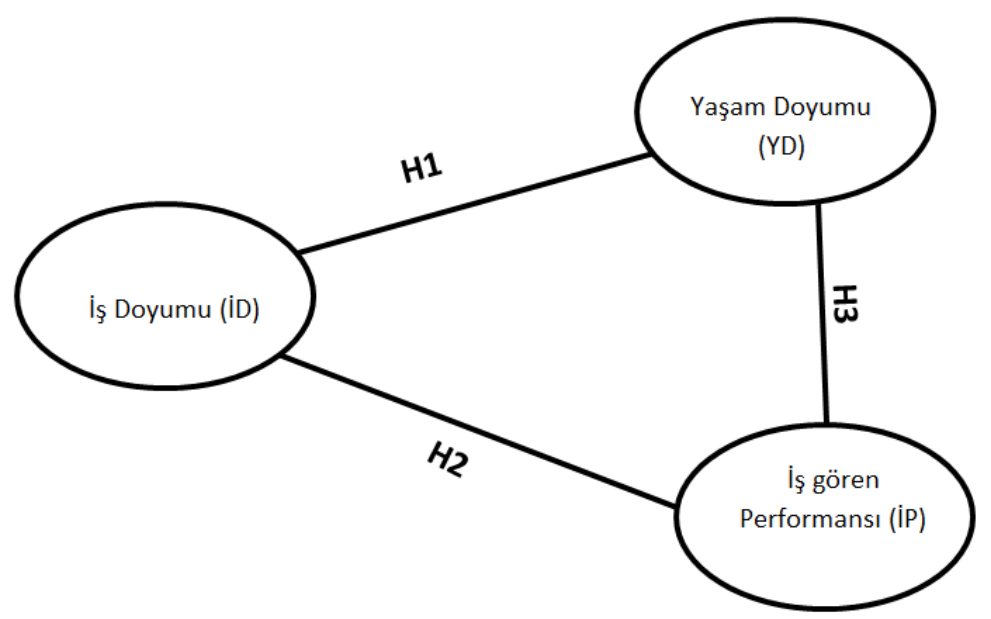

Şekil 1. Araştırmanın Modeli

Araştırmanın amacına dayanarak aşağıdaki hipotezler test edilmiştir:

H1: İş doyumu ile yaşam doyumu arasında ilişki vardır.

H2: İş doyumu ile işgören performansı arasında ilişki vardır.

H3: Yaşam doyumu ile işgören performansı arasında ilişki vardır.

\section{KAVRAMSAL ÇERÇEVE}

\section{1. İş Doyumu}

İşletmelerde işgörenlerin işlerine karşı geliştirdikleri çeşitli duygusal tutumları vardır. Duygusal tutumların ortaya çıkmasında en önemli etken insan ihtiyaçlarıdır. İş yerinde işgörenlerin amaç ve değerlerinin, ihtiyaçlarının yerine getirilmesi ile oluşan olumlu duygusal tepkiler iş doyumu olarak adlandırılır. Araştırmalar iki tür iş memnuniyeti olduğunu göstermektedir; çalışanların genel olarak iş memnuniyeti, diğeri ise yapılan işin bir veya birkaç bölümünden memnun hissetmek. Bunlar da çalışma koşulu, cari ücret, terfi fırsatı, iş güvenliği ve denetim olarak kabul edilen faktörlerdir (Ohunakin vd. 2019: 445). Günün büyük bir kısmını işyerinde geçiren işgörenler için fiziksel, bireysel ve örgüt içi ilişkiler anlamında çalışma ortamı iş doyumu ve yaşam kalitesini önemli ölçüde etkiler. Havalandırma, 1sı, 1şık, kalabalık ve gürültü işyerindeki fiziksel faktörlerdir. Bireysel faktörler ise işgörenin üstlendiği sorumlulukların derecesi, işe ait üstlenilen rol ve bireysel iş yükü gibi faktörlerdir. Bireysel anlamda farklı yaş gruplarında da iş doyumu farklı oranlarda ortaya çıkar (Traymbak ve Kumar, 2018:29). Örgüt içi ilişkiler ise gerek amirlerle gerekse iş arkadaşları ile olan ilişkiler faktörüdür. Bu faktörlerin yanısıra işyerinin kurumsal yapısına ilişkin katı yönetimsel faaliyetler iş doyumunu olumlu ya da olumsuz etkilemektedir. İş doyumu olumlu olduğu zaman başarı ve verimliliği de olumlu etkiler, olumsuz olduğu zaman işgörenlerin özel hayatındaki sıkıntılarla birlikte yorgunluk, huzursuzluk, öfke hatta depresyon gibi sonuçlar ortaya çıarır. İş doyumunun azalması uzun vadeli olarak devam ettiği taktirde fiziksel sorunlara da yol açar. Bu sorunlar işgörenin performansını düşürür, gerek özel yaşamında gerekse iş yerinde çevresiyle çatışma ortamı oluşturur, işini yeterince iyi yapmasını engeller (Batıgün ve Şahin, 2006:33). Genellikle iş yerlerinde çatışmanın kaynağ işgörenlerin iş doyumunun azalması olarak düşünülür (Zhao vd., 2018:493). İş doyumunun azalması aynı zamanda örgütsel bağlılığın da azalmasını ve işten ayrılma niyetini arttırır (DiPietro vd., 2019: 143). 


\subsection{Yaşam Doyumu}

Yaşam memnuniyeti kavramı, ilk kez 1961 yılında Neugarten tarafından tanımlanmıştır. Yaşam doyumu, kişinin hedefleri olduğu ve bu hedeflere ulaşmada mutlu olup olmaması ile ilgili hayata karşı genel tutumudur. Bu düşünce kişinin çalışma hayatı dışındaki tepkilerini açıklar. Günlük yaşamda mutlu olup olmamak, psikolojik ve fiziksel olarak iyi hissedip etmemek, sosyal ve ekonomik anlamda güvenli olup olmamak, yaşam doyumunu etkileyen faktörlerdir (Demirel, 2014: 4926). Yaşam doyumu, kişilerin yalnızca boş zamanları ile ilgili değildir aynı zamanda çalışma hayatına ve yaşamlarının diğer alanlarına yönelik tutumlarıyla da ilgilidir, kişilerin istekleri ile gerçekte sahip oldukları şeyleri karşılaştırarak değerlendirmeleri sonucu yaşam doyumu ortaya çıkar (Doğan vd., 2015: 1802). Bireyler yaşam içinde farklı roller üstlenebilirler, çalışan, ebeveyn, eş veya arkadaş rolünü aldığında yaşamın çeşitli alanlarında bulunabilir, yaşamından memnun olabilir ya da mutsuz olabilir. Mutlu olan bireyler çevresindeki insanlara daha iyi davranabilirler, bu özellik iş yaşamında daha önemlidir, çünkü iş yaşamında mutluluk, iş doyumu sonuçta verimliliği arttırır (Toker, 2012: 191). Bazı çalışmalar işyerinde çalışma saatleri ile mutluluk arasında negatif bir ilişki olduğunu göstermiştir. Çalışma saatleri, tatil saat ve günleri çalışan mutluluk/mutsuzluğu üzerinde önemli rol oynar. Yeterince tatil olanağı çalışanların yaratıcılığı üzerinde etkili olmaktadır. Boş zamanların yanısıra maaş düzeyi ve terfi, kariyer başarısı da çalışan mutluluğunda önemli bir rol oynamaktadır. Zorlu görevler, dakiklik, kişinin işine ek zaman ve enerji yatırımı, işinde inisiyatif kullanımı çalışanların kuruma olan bağlılıklarını yansıtan göstergelerdir, bütün bunlar aynı zamanda kariyer memnuniyeti ile ilişkili olduğu ve verimlilikte önemli olduğu düşünülür (Kawakubo ve Oguchi, 2019: 241).

\section{3. İşgören Performansı}

Genel olarak performans, kişinin kapasitesini kullanım düzeyi olarak tanımlanabilir (Uludağ, 2018: 179). İşgören performansı, belirli bir süre içinde işgörenin gerçekleştirdiği iş görme derecesi ve örgüt içinde verimli bir şekilde başarıyı hedeflemesi olarak tanımlanır (Saltık, 2016: 38). Bir başka deyişle, işgörenin bir işin yapılabilmesi için gerekli olan genel kabul görmüş zaman sınırı içinde işyerinde görev ve sorumluluklarını yerine getirmesidir. İşgören performansı yalnızca işgörenler açısından değil aynı zamanda işletmenin hedeflerine ulaşmasını da gerçekleştirir (Ayub ve Islam, 2018:830). Performans derecesi hiyerarşik anlamda düşünülürse görev ve sorumluluklar astlardan yönetim kademesine doğru artan oranlarda farklılıklar gösterir. Astların istenilen oranda iyi bir performans göstermesinde ise yönetimin işgörenleri yönlendirmeleri çok önemlidir. Öncelikle yönetim işletmenin başarısını arttırabilmek, amaçlar doğrultusunda sektörde başarılı faaliyetleri gerçekleştirebilmek amacıyla işgörenlerin başarıya bağlı olarak ücretlendirilmesi, ödüllendirilmesi, terfisi gibi motivasyon anlamında bazı teknik ve yöntemler kullanmaya gerek duyar. Bu teknik ve yöntemlerin işletmede devamlı ve akılcı olması performans yönetiminin başarısında çok önemlidir (Yılmaz, 2015: 18).

\section{YÖNTEM}

Araştırmanın evrenini Türkiye'de Turizm Bakanlığı'na bağlı 4 ve 5 yıldızlı otel çalışanları oluşturmaktadır. Evrendeki araştırma grubuna ulaşmanın zorluğundan dolayı örneklem seçilmiştir. Örneklem grubu Ankara ilinde bulunun 4 ve 5 yıldızlı otel işletmeleri çalışanlarından oluşmaktadır. Örneklem grubunda bulunan Ankara ilindeki tüm 4 ve 5 yıldızlı otellerde çalışanlara anketler elden verilerek doldurmaları istenilmiştir. Anket formunu dolduran 319 kişi araştırmanın veri tabanını oluşturmuştur.

Araştırmada birincil ve ikincil veri kaynaklarından yararlanılmıştır. Bu kapsamda daha önce yapılmış çalışmalar, makaleler, tezler gibi yazılı kaynaklar taranmıştır. Bu çalışmalar ışığında 4 ve 5 yıldızlı otel işletmeleri çalışanlarının iş doyumu ile yaşam doyumu arasında, iş doyumu ile 
iş görenlerin performansları arasında ve yaşam doyumu ile iş görenlerin performansları arasında ilişkinin bulunup bulunmadığını saptamaya yönelik anketler uygulanmıştır.

Veri toplama aracı dört bölümden oluşmakta olup; birinci bölümde araştırmaya katılan çalışanlar ile ilgili genel bilgilere ilişkin sorulara, ikinci bölümde iş doyumu ölçeği, üçüncü bölümde yaşam doyumu ölçeği, dördüncü bölümde işgören performansı ölçeğine yer verilmiştir.

10 sorudan oluşan iş doyumu ölçeği Tezer (1991), 5 soruluk yaşam doyumu ölçeği Diener vd. (1985) ve Sigler ve Pearson (2000)' 1n, Kirkman ve Rosen (1999)'dan aldığı ve Çöl (2008) tarafından Türkçeye çevrilen 4 sorudan oluşan işgören performansı ölçeği kullanılmıştır.

\section{BULGULAR}

Araştırmanın örneklem grubunu oluşturan otel çalışanlarının genel yapısına yönelik tanıtıcı frekans ve yüzde dağılımları Tablo-1 de gösterilmiştir.

Tablo 1. Örneklem Grubuna ilişkin Tanımlayıcı İstatistikler

\begin{tabular}{|c|c|c|}
\hline Yaş & Sayı (f) & Yüzde (\%) \\
\hline 25 Yaş ve Altı & 37 & 11,6 \\
\hline 26-30 Yaş Arası & 45 & 14,1 \\
\hline 31-35 Yaş Arası & 51 & 16,0 \\
\hline 36-40 Yaş Arası & 59 & 18,5 \\
\hline 41 Yaş Üzeri & 127 & 39,8 \\
\hline Toplam & 319 & 100,0 \\
\hline Cinsiyet & Sayı (f) & Yüzde (\%) \\
\hline Kadın & 194 & 60,8 \\
\hline Erkek & 125 & 39,2 \\
\hline Toplam & 319 & 100,0 \\
\hline Medeni Durum & Sayı (f) & Yüzde (\%) \\
\hline Evli & 187 & 58,6 \\
\hline Bekar & 132 & 41,4 \\
\hline Toplam & 319 & 100,0 \\
\hline Eğitim & Sayı (f) & Yüzde (\%) \\
\hline İlköğretim & 9 & 2,8 \\
\hline Lise & 89 & 27,9 \\
\hline Önlisans & 31 & 9,7 \\
\hline Lisans & 134 & 42,0 \\
\hline Lisans Üstü & 56 & 17,6 \\
\hline Toplam & 319 & 100,0 \\
\hline Sektörde Çalışma Yılı & Sayı (f) & Yüzde (\%) \\
\hline 1 Yıldan Az & 23 & 7,2 \\
\hline 1-5 Yil Arası & 77 & 24,1 \\
\hline 6-10 Yil Arası & 71 & 22,3 \\
\hline 11-15 Yil Arası & 46 & 14,4 \\
\hline 16 Yil ve Üzeri & 102 & 32,0 \\
\hline Toplam & 319 & 100,0 \\
\hline
\end{tabular}

Araştırmaya katılan çalışanların yaş dağılımlarına Tablo-1 den bakıldığında; \%11,6'sı 25 yaş ve altı, \%145'1 i 26-30 yaş arası, \%16,0' 1 31-35 yaş arası, \%18,5'i 36-40 yaş arası ve \%39,8'inin 41 yaş ve üzeri olduğu görülmektedir. Örneklem grubundaki çalışanların büyük bir bölümünün 41 yaş ve üzeri olduğu dikkat çekmektedir. 
Araştırmaya göre çalışanların \%60,8' i kadın ve \%39,2'si erkektir. Örneklem grubunun çoğunluğu kadınlardan oluşmaktadır, gerek sayı olarak gerekse de yüzdelik dağılımdaki farkın çok fazla olduğu görülmektedir.

Araştırmaya katılanların \%58,6'sının evli, \%41,4'ünün ise bekar olduğu görülmektedir.

Araştırmaya katılanların eğitim durumları dağılımları; \%2,8'i ilköğretim \%27,9'u lise, \%9,7si ön lisans, \%42,0'si lisans ve \%17,6'llk dilimde ise lisans üstü eğitime sahip olanların yer aldığ görülmektedir. Dolayısıyla çalışanların büyük çoğunluğunun lisans mezunları olduğu dikkati çekmektedir.

Araştırmaya katılanların çalışma yılı yüzde ve frekans dağılımına bakıldığında; çalışanların $\% 7,2^{\prime}$ si 1 yıldan az, \%24,1'i 1 ve 5 yıl arası, \%22,3'ü 6 ve 10 yıl arası, \%14,4,'ü 11 ve 15 yıl arasında $\% 32$ 'sinin ise 16 yıl ve üzerinde çalışma süreleri vardır.

Tablo 2. İş Doyumu Yaşam Doyumu ve İşgören Performansı Arasındaki Korelasyon Analizi

\begin{tabular}{|l|l|c|c|c|}
\hline \multicolumn{2}{|l|}{} & İş Doyumu & Yaşam Doyumu & $\begin{array}{c}\text { İşören } \\
\text { Performans }\end{array}$ \\
\hline \multirow{3}{*}{ İş Doyumu } & $\mathrm{r}$ & 1 &, $169^{* *}$ &, $313^{* *}$ \\
\cline { 2 - 5 } & $\mathrm{p}$ & &, 002 &, 000 \\
\cline { 2 - 5 } & $\mathrm{n}$ & 319 & 319 & 319 \\
\hline \multirow{3}{*}{ Yaşam Doyumu } & $\mathrm{r}$ &, $169^{* *}$ & 1 &, 074 \\
\cline { 2 - 5 } & $\mathrm{p}$ &, 002 & & 319 \\
\cline { 2 - 5 } & $\mathrm{n}$ & 319 & 319 & 1 \\
\hline \multirow{2}{*}{ İşgören Performansı } & $\mathrm{r}$ &, $313^{* *}$ &, 074 & 319 \\
\cline { 2 - 5 } & $\mathrm{p}$ &, 000 &, 189 & 319 \\
\hline
\end{tabular}

** Korelasyon 0,01 seviyesinde anlamlıdır.

Araştırmaya katılan örneklem grubunun iş doyumu ile yaşam doyumu arasındaki ilişkiye bakılmış olup $p<0,01$ önem düzeyinde anlamlı bir ilişki tespit edilmiştir ve ilişkinin şiddeti $r=, 169$ olduğu görülmektedir. Diğer bir ifade ile iş doyumu ve yaşam doyumu arasında dikkate değer bir ilişki bulunmuştur. Yapılan analizde bulunan korelasyon katsayısının anlamlılığın oldukça yüksek olduğu $(p=0,002)$ tespit edilerek $\mathbf{H 1}$ hipotezi yeterli kanitla desteklenmiştir.

Araştırmaya katılan örneklem grubunun iş doyumu ile iş gören performansı arasındaki ilişkiye bakılmış olup $\mathrm{p}<0,01$ önem düzeyinde anlamlı bir ilişki tespit edilmiştir ve ilişkinin şiddeti $r=, 313$ olduğu görülmektedir. Diğer bir ifade ile iş doyumu ve işgören performansı arasında dikkate değer bir ilişki bulunmuştur. Yapılan analizde bulunan korelasyon katsayısının anlamlılığ oldukça yüksek olduğu $(\mathrm{p}=0,000)$ tespit edilerek $\mathbf{H 2}$ hipotezi yeterli kanıtla desteklenmiştir.

Araştırmaya katılan örneklem grubunun yaşam doyumu ile işgören performansı arasındaki ilişkiye bakılmış olup $\mathrm{p}<0,01$ önem düzeyinde anlamlı bir ilişki tespit edilememiştir. Dolayısıyla yaşam doyumu ile işgören performansı arasında istatistiksel olarak dikkate değer bir ilişki bulunamamıştır. Yapılan analizde bulunan korelasyon katsayısının anlamlılığı $(p=0,189)$ tespit edilerek H3 hipotezi yeterli kanıtla desteklenememiştir. 
Tablo 3. Yaş Gruplarına Göre Çalışanların İş Doyumu Yaşam Doyumu ve İş gören Performansı Arasındaki Farklılaşma (ANOVA)

\begin{tabular}{|c|c|c|c|c|c|c|}
\hline \multicolumn{2}{|c|}{ Yaş Grupları } & Sayı (f) & X (Mean) & s.s. & $\mathbf{F}$ & $\mathrm{p}$ \\
\hline \multirow{6}{*}{ İş Doyumu } & 25 Yaş ve Altı & 37 & 3,6486 & 96079 & \multirow{6}{*}{1,404} & \multirow{6}{*}{,232 } \\
\hline & 26-30 Yaş Arası & 45 & 3,6356 & ,75593 & & \\
\hline & 31-35 Yaş Arası & 51 & 3,7392 & ,76918 & & \\
\hline & 36-40 Yaş Arası & 59 & 3,6983 & 69344 & & \\
\hline & 41 Yaş ve Üzeri & 127 & 3,8898 & ,80355 & & \\
\hline & Toplam & 319 & 3,7665 & ,79450 & & \\
\hline \multirow{6}{*}{ Yaşam Doyumu } & 25 Yaş ve Altı & 37 & 3,1351 & ,72733 & \multirow{6}{*}{2,317} & \multirow{6}{*}{, 057 } \\
\hline & 26-30 Yaş Arası & 45 & 3,4222 & 61084 & & \\
\hline & 31-35 Yaş Arası & 51 & 3,2392 & ,70769 & & \\
\hline & 36-40 Yaş Aras1 & 59 & 3,2949 & ,75782 & & \\
\hline & 41 Yaş ve Üzeri & 127 & 3,4866 & ,78744 & & \\
\hline & Toplam & 319 & 3,3618 & ,74609 & & \\
\hline \multirow{6}{*}{ İşgören Performansı } & 25 Yaş ve Altı & 37 & 3,7703 & ,99718 & \multirow{6}{*}{1,234} & \multirow{6}{*}{,296 } \\
\hline & 26-30 Yaş Arası & 45 & 3,8889 & ,74726 & & \\
\hline & 31-35 Yaş Arası & 51 & 3,8284 & 87105 & & \\
\hline & 36-40 Yaş Arası & 59 & 3,5932 & ,99773 & & \\
\hline & 41 Yaş ve Üzeri & 127 & 3,5906 & 1,08912 & & \\
\hline & Toplam & 319 & 3,6920 & ,98782 & & \\
\hline
\end{tabular}

Araştırmaya katılan örneklem grubunun yaş değişkeni açısından ş doyum düzeylerinde bir farkılaşma olup olmadığına bakılmış olup, 0,05 önem düzeyinde bir farklılaşma tespit edilememiştir. Diğer yandan yaşam doyumu açısından da 0,05 önem düzeyinde bir farklılaşma bulunamamıştır. Son olarak işgören performansı düzeylerinde farklılaşmaya bakılmış olup yine 0,05 önem düzeyinde bir farklılaşma tespit edilememiştir.

Dolayısıyla, Her üç boyutta da yaş grupları değişkeni açısından bakıldığında bir farklılaşma bulunmamaktadır.

Tablo 4. Cinsiyete Göre Çalışanların İş Doyumu Yaşam Doyumu ve İşgören Performansı Arasındaki Farklılaşma (t-testi)

\begin{tabular}{|l|l|r|r|r|r|r|}
\hline \multicolumn{2}{|c|}{ Cinsiyet } & Sayı (f) & X (Mean) & \multicolumn{1}{c|}{ s.s. } & \multicolumn{1}{c|}{ t } & \multicolumn{1}{c|}{ p } \\
\hline \multirow{3}{*}{ İş Doyumu } & Kadın & 125 & 3,6008 &, 83487 & & \\
\cline { 2 - 6 } Yaşam Doyumu & Erkek & 194 & 3,8732 &, 75034 & 3,027 &, 003 \\
\hline \multirow{2}{*}{ İşgören Performansı } & Kadın & 194 & 3,4134 &, 73465 & & \\
& Erkek & 125 & 3,2816 &, 75950 & 1,544 &, 124 \\
\cline { 2 - 6 } & Kadın & 194 & 3,7848 &, 97694 & & \multirow{2}{*}{, 036} \\
\cline { 2 - 5 } & Erkek & 125 & 3,5480 &, 99124 & & \\
\hline
\end{tabular}

Araştırmaya katılan örneklem grubunun cinsiyet değişkenine göre iş doyumu, yaşam doyumu ve işgören performansında bir farklılaşma olup olmadığı araştırılmış ve iş doyumu ile işgören performansı ile cinsiyet arasında anlamlı bir farklılaşma tespit edilirken yaşam doyumu ile cinsiyet arasında anlamlı bir farklılaşma tespit edilememiştir. $(\mathrm{p}<.05)$. 
Tablo 5. Medeni Duruma Göre Çalışanların İş Doyumu Yaşam Doyumu ve İşgören Performansı Arasındaki Farklılaşma (t-testi)

\begin{tabular}{|l|l|c|c|c|c|c|}
\hline \multicolumn{2}{|c|}{ Medeni Durum } & Sayı (f) & X (Mean) & s.s. & t & p \\
\hline \multirow{3}{*}{ İş Doyumu } & Evli & 187 & 3,8316 &, 76321 & & \\
\cline { 2 - 6 } & Bekar & 132 & 3,6742 &, 83104 & 1,747 & \multirow{2}{*}{082} \\
\hline \multirow{3}{*}{ Yaşam Doyumu } & Evli & 187 & 3,4075 &, 77192 & & \\
\cline { 2 - 5 } & Bekar & 132 & 3,2970 &, 70570 & 1,304 & \multirow{2}{*}{, 193} \\
\hline \multirow{2}{*}{ İşgören Performansı } & Evli & 187 & 3,7219 &, 95789 & & \\
\cline { 2 - 5 } & Bekar & 132 & 3,6496 & 1,03094 & \multirow{2}{*}{, 643} &, 521 \\
\hline
\end{tabular}

Araştırmaya katılan örneklem grubunun iş doyumu ile medeni durum değişkenine göre $p<.05$ anlamlılık seviyesinde anlamlı bir farklılık tespit edilmiştir. Medeni durum değişkenine göre, Yaşam doyumu ve işgören performansında bir farklılaşma olup olmadığı araştırılmış ve iş doyumu ile işgören performansı ile medeni durum arasında $p<.05$ anlamlılık seviyesinde bir farklılaşma tespit edilememiştir.

Tablo 6. Eğitim Gruplarına Göre Çalışanların İş Doyumu Yaşam Doyumu ve İşgören Performansı Arasındaki Farklılaşma (ANOVA)

\begin{tabular}{|c|c|c|c|c|c|c|}
\hline \multicolumn{2}{|c|}{ Eğitim Grupları } & Sayı (f) & X (Mean) & s.s. & $\mathbf{F}$ & p \\
\hline \multirow{6}{*}{ İş Doyumu } & İlköğretim & 9 & 4,1444 & ,95146 & \multirow{6}{*}{893} & \multirow{6}{*}{,468 } \\
\hline & Lise & 89 & 3,7854 & ,88607 & & \\
\hline & Önlisans & 31 & 3,7065 & ,83584 & & \\
\hline & Lisans & 134 & 3,7082 & ,76532 & & \\
\hline & Lisansüstü & 56 & 3,8482 & 65059 & & \\
\hline & Toplam & 319 & 3,7665 & ,79450 & & \\
\hline \multirow{6}{*}{ Yaşam Doyumu } & İlköğretim & 9 & 3,2667 & ,64807 & \multirow{6}{*}{, 594} & \multirow{6}{*}{ 667 } \\
\hline & \begin{tabular}{|l} 
Lise \\
\end{tabular} & 89 & 3,2854 & ,79595 & & \\
\hline & Önlisans & 31 & 3,4645 & ,75080 & & \\
\hline & Lisans & 134 & 3,3597 & ,64553 & & \\
\hline & Lisansüstü & 56 & 3,4464 & 89686 & & \\
\hline & Toplam & 319 & 3,3618 & ,74609 & & \\
\hline \multirow{6}{*}{ İşgören Performansı } & İlköğretim & 9 & 3,4444 & 1,26106 & \multirow{6}{*}{2,029} & \multirow{6}{*}{,090 } \\
\hline & Lise & 89 & 3,5309 & 1,06987 & & \\
\hline & Önlisans & 31 & 3,4839 & 1,16715 & & \\
\hline & Lisans & 134 & 3,7705 & 94841 & & \\
\hline & Lisansüstü & 56 & 3,9152 & ,72029 & & \\
\hline & Toplam & 319 & 3,6920 & ,98782 & & \\
\hline
\end{tabular}

Örneklem grubundaki çalışanların eğitim durumları gözönünde bulundurularak yapılan Anova testinde; katılımcıların iş doyumu, yaşam doyumu ve işgören performansı boyutlarında eğitim durumu değişkeninin $p<.05$ anlamlılık seviyesinde bir farklılaşma tespit edilememiştir. 
Tablo 7. Çalışma Süresi (Kıdem) Değişkeni Açısından çalışanların İş Doyumu Yaşam Doyumu ve İşgören Performansı Arasındaki Farklılaşma (ANOVA)

\begin{tabular}{|c|c|c|c|c|c|c|}
\hline \multicolumn{2}{|c|}{ Sektördeki Çalışma Yılı (Kıdem) } & Sav (f) & X (Mean) & s.s. & F & $\mathbf{p}$ \\
\hline \multirow{6}{*}{ İş Doyumu } & $1-5$ & 23 & 4,0000 & ,79772 & \multirow{4}{*}{1,741} & \multirow{4}{*}{ 141 } \\
\hline & $6-10$ & 77 & 3,6377 & ,85564 & & \\
\hline & $11-15$ & 71 & 3,7042 & ,88615 & & \\
\hline & $16-20$ & 46 & 3,7043 & ,72387 & & \\
\hline & 21 ve üzeri & 102 & 3,8824 & 69073 & & \\
\hline & Toplam & 319 & 3,7665 & ,79450 & & \\
\hline \multirow{6}{*}{ Yaşam Doyumu } & $1-5$ & 23 & 3,2261 & ,43612 & \multirow{6}{*}{1,328} & \multirow{6}{*}{,259 } \\
\hline & $6-10$ & 77 & 3,2623 & 68230 & & \\
\hline & $11-15$ & 71 & 3,3211 & ,71752 & & \\
\hline & $16-20$ & 46 & 3,3783 & ,77658 & & \\
\hline & 21 ve üzeri & 102 & 3,4882 & ,84036 & & \\
\hline & Toplam & 319 & 3,3618 & ,74609 & & \\
\hline \multirow{6}{*}{ İşgören Performansı } & $1-5$ & 23 & 4,0109 & ,68456 & \multirow{6}{*}{2,913} & \multirow{6}{*}{,022 } \\
\hline & $5-10$ & 77 & 3,6623 & ,94396 & & \\
\hline & $10-15$ & 71 & 3,9437 & ,86520 & & \\
\hline & $15-20$ & 46 & 3,6359 & ,96135 & & \\
\hline & 21 ve üzeri & 102 & 3,4926 & 1,12215 & & \\
\hline & Toplam & 319 & 3,6920 & ,98782 & & \\
\hline
\end{tabular}

Çalışma yılı göz önünde bulundurularak yapılan Anova testinde örneklem grubundaki katılımcıların iş doyumu ve yaşam doyumu kıdem yılı değişkeni açısından $\mathrm{p}<.05$ anlamlılık seviyesinde bir farklılaşma tespit edilememişken, işgören performansı ile kıdem yılı değişkeni açısından $\mathrm{p}<.05$ anlamlılık seviyesinde bir farklılaşma tespit edilmiştir.

\section{SONUÇ VE TARTIŞMA}

İş doyumu, yaşam doyumu ve işgören performansı her çalışanın hayatında bulunan kavramlardır. Bireyin işinde doyuma ulaşmasından dolayı kendine güveni, yaşam kalitesi ve hayata karşı pozitif bir bakış açısına sahip olması, daha sakin yaşaması, hatta hayattan keyif almasının bazı sonuçları vardır. Bu sonuçlar motivasyonu yükseltir, motivasyona bağlı olarak da performans artışı meydana gelir. Performans artışı ise verimliliği sağlar, bu durum da iş doyumu, yaşam doyumu ve işgören performansı terimlerinin birbiriyle olan ilişkisini açıklar.

İşverenler işgörenlerin iş doyumu, yaşam doyumu ve performansları konusuna ağırlıklı olarak önem vermelidir, ayrıca verilen önemin sürekliliğini sağlamaları, çalışanların iş doyumunu yüksek tutmaları ve şirket bilincini, örgüt kültürünü bu yönde sürdürmeleri gerekmektedir. İsgören memnuniyetinin sağlanması performansına da etki edecektir. Bu olumlu etki sayesinde müşteriler de olumlu yönde etkilenecektir. Kısacası, çalışanların müşterilerle birebir iletişime geçtikleri düşünüldüğünde, çalışandan kaynaklı pozitif ya da negatif davranışlar müşteriye, kuruma, çalışma arkadaşlarına, yönetime de yansıyacak, müşteriler işletme hakkında iyi ya da kötü görüş sahibi olurken ya da hizmet almak ya da almamak isterken kurum içinde de bu davranışlardan kaynaklı çatışma kriz stres söz konusu olabileceği gibi olumlu yansımasında da motive olmuş güçlü bir örgüt yapısı ortaya çıkabilecektir.

$\mathrm{Bu}$ çalışmada yapılan analizlerin sonuçlarına göre; iş doyumu ve yaşam doyumu arasında, iş doyumu ile işgören performansı arasında anlamlı bir ilişki bulunmuştur. Bu da H1 ve H2 hipotezlerinin yeterli kanıtla desteklendiğini göstermektedir. Bu bilgi araştırmaya katılan 
örneklem grubunun iş doyumu ile yaşam doyumu arasında ve iş doyumu ile işgören performansı arasında bir ilişki olduğunu göstermektedir. Demografik özelliklerden sektörde çalışma yılına bakıldığında 16 yıl ve üzerinde çalışan işgörenlerin sayısının fazla olması, emek yoğun özelliği olan turizm sektöründe önemlidir ve iş doyumunu işaret eden bir özelliktir. Avşaroğlu vd. (2005: 127) öğretmenlerin iş doyumuna ilişkin yaptıkları çalışmada iş doyumunun yüksek olmasının tükenmişliği azalttığı yönünde bir sonuca ulaşmış olmalarının performanslarına olumlu bir etki yarattı̆̆1 yönünde düşünülebilir. Tarlan ve Tütüncü'nün (2001: 161) konaklama işletmelerinde yaptıkları araştırmada, iş doyumuna etki eden faktörlerin işin kendisi, amirler, ücret, iş arkadaşları ve terfi olanakları olduğunu saptamışlardır. Aynı çalışmada Herzberg' in çift etmen teorisinin de desteklendiği ve ücretin iş doyumuna etki eden bir faktör olmakla birlikte, ana faktör olmadığı, güdülemenin de doğrudan bir etki yaratmadığı belirtilmiştir. Saltık (2016: 96) konaklama işletmelerinde uyguladığ 1 tez çalışmasında iş stresinin performans üzerinde anlamlı bir etkisi olduğu sonucuna varmıştır ve iş doyumu ya da doyumsuzluğunun performansı etkilediğini belirtmiştir.

Araştırmaya katılan örneklem grubunun yaşam doyumu ile işgören performansı arasında ise istatistiksel olarak anlamlı bir ilişki bulunamamıştır, bir başka deyişle $\mathrm{H} 3$ hipotezi yeterli kanıtla desteklenememiştir. Bu bilgi de araştırmaya katılan örneklem grubunun yaşam doyumu ile işgören performansı arasında bir ilişki olmadığını göstermektedir. Turizm sektöründe çalışma koşullarının yoğun olması nedeniyle işgörenlerin günlük yaşantıda bazı isteklerini gerçekleştirememeleri, ailelerine yeterince zaman ayıramamaları gibi yaşam doyumuna ilişkin bazı faktörlerin performansları ile bir ilişkisinin olmadığı yönünde düşünülebilir.

$\mathrm{Bu}$ sonuçlar anketlerin uygulandığı otel işletmesi çalışanlarının çalıştıkları işyerinde motive olduklarını göstermektedir. Genel olarak yaşam doyumları ile işgören performansları arasında anlamlı bir ilişkinin olmaması ise işletme dışındaki yaşamları ve işgörenlerin kişilik özelliklerinin birbirlerinden farklı olması nedeniyle iş performansı ile anlamlı bir ilişki bulunmamaktadır.

Araştırmanın bu bölümünde, araştırma bulgularına dayalı olarak uygulayıcılar ve konu ile ilgili çalışma yapacak araştırmacılara yönelik olarak şu önerilerde bulunulabilir:

1. İş doyumu, yaşam doyumu ve işgören performansı arasındaki ilişki bölgesel farklılıkları da görmek üzere çeşitli yerlerde araştırılabilir.

2. Merkez konumundaki kentlerdeki 4 ve 5 yıldızl tespit edilen otellerde de hipotezler test edilebilir ve her üç boyutunda algı düzey seviyelerini yükseltmek için çalışmalar yapılabilir.

3. Araştırma grubundaki çalışanların iş doyumu, yaşam doyumu ve işgören performansı arasındaki ilişki yönetici davranışları açısından incelenebilir.

4. Araştırma grubundaki çalışanların iş doyumunun, yaşam doyumu ve işgören performansı üzerine etkileri araştırılabilir.

5. Çalışanların eğitim seviyeleri demografik değişkeni ile karşılaştırmalar yapılarak araştırma kapsamı derinleştirilebilir.

\section{KAYNAKÇA}

Avşaroğlu, S., Deniz, M. E. ve Kahraman, A. (2005). Teknik Öğretmenlerde Yasam Doyumu İş Doyumu ve Mesleki Tükenmişlik Düzeylerinin İncelenmesi. Selçuk Üniversitesi Sosyal Bilimler Enstitüsü Dergisi, 14, 115-129.

Ayub, N. B. ve Islam, M. K. (2018). The Effects of Employee Engagement on Employee Performance in the Hotel Industry in Kelantan, Global Business and Management Research: An International Journal, 10 (3), Special Issue. 
Batıgün, A. D. ve Şahin, N. H. (2006). İş Stresi Ve Sağlık Psikolojisi Araştırmaları İçin İki Ölçek: A-Tipi Kişilik Ve İş Doyumu, Türk Psikiyatri Dergisi, 17 (1), 32-45.

Çöl, G. (2008). Algılanan Güçlendirmenin İşgören Performansı Üzerine Etkileri, Doğuş Üniversitesi Dergisi, 9 (1), 35-46.

Demirel, H. (2014). An investigation of the Relationship between Job and Life Satisfaction among Teachers, Procedia - Social and Behavioral Sciences 116, 4925 - 4931

Diener, E.; Emmons, R.A.; Larsen, R. J. ve Griffin, S. (1985). The Satisfaction with Life Scale, Journal of Personality Assessment, 49, 71-75.

DiPietro, R. B.; Moreo, A. ve Cain, L. (2020 Well-being, Affective Commitment and Job Satisfaction: İnfluences on Turnover İntentions in Casual Dining Employees, Journal of Hospitality Marketing \& Management, 29 (2), 139-163, DOI: 10.1080/19368623.2019.1605956.

Doğan, B. G.; Laçin, E. ve Tutal, N. (2015). Predicatives of the Workers' Burnout Level: Life Satisfaction and Social Support, Procedia - Social and Behavioral Sciences 191, 1801 - 1806.

Kawakubo, A, ve Oguchi, T. (2019). Recovery Experiences during Vacations Promote Life Satisfaction Through Creative Behavior, Tourism Management Perspectives 30, 240-250.

Ohunakin, F.; Adeniji, A. A.;. Oludayo, O. A.; Osibanjo A. O. ve Oduyoye O. O. (2019) Employees' Retention in Nigeria's Hospitality Industry: The Role of Tansformational Leadership Style and Job Satisfaction, Journal of Human Resources in Hospitality \& Tourism, 18 (4), 441-470, DOI: 10.1080/15332845.2019.1626795.

Saltık, Z. (2016). Stresin İşgören Performansına ve İşten Ayrılma Niyetine Etkisi: Konaklama İşletmelerinde Bir Uygulama, (Yayımlanmamış Yüksek Lisans Tezi), Nevşehir Hacı Bektaş Veli Üniversitesi/ Sosyal Bilimler Enstitüsü Turizm İşletmeciliği Anabilim Dalı.

Tarlan, D. Ve Tütüncü, Ö. (2001). Konaklama İşletmelerinde Başarım Değerlemesi ve İşdoyumu Analizi, Dokuz Eylül Üniversitesi Sosyal Bilimler Enstitüsü Dergisi, 3 (2).

Tezer, E. (1991). İş Doyumu Ölçeği, Hacettepe Üniversitesi, Sosyal Hizmetler Yüksekokulu Dergisi, 9 (1-2-3), 55-76.

Toker, B. (2012). Life Satisfaction Among Academicians: an Empirical Study on the Universities of Turkey, Procedia - Social and Behavioral Sciences, 47, 190 - 195.

Traymbak, S. ve Kumar, P. (2018). Impact of Job Characteristics and Role Stress on Job Satisfaction in Relation to Age of the Employees: an Assessment, The IUP Journal of Organizational Behavior, 17 (2).

Uludağ, G. (2018). Örgütsel Bağlılık İle İşgören Performansı İlişkisini İncelemeye Yönelik Bir Alan Araştırması, Bitlis Eren Üniversitesi Sosyal Bilimler Enstitüsü Dergisi, 7 (1).

Yılmaz, E. (2015). İşgören İş Tatmini İle İşgören Performansı Arasındaki İlişkinin İncelenmesi Üzerine Bir Araştırma, (Yayımlanmamış Yüksek Lisans Tezi), T.C. Hasan Kalyoncu Üniversitesi/ Sosyal Bilimler Enstitüsü İşletme Anabilim Dalı İşletme Bilim Dalı.

Zhao, K.; Zhang, M.; Kraimer, M. L.ve Yang, B. (2018). Source Attribution Matters: Mediation and Moderation Effects in the Relationship between Work-to-Family Conflict and Job Satisfaction. Journal of Organizational Behavior, 40, 492-505. 